\title{
Overcoming Naturalism from Within: Dilthey, Nature, and the Human Sciences
}

\begin{abstract}
Dilthey's middle works offer alternative strategies for interpreting the debate between naturalism and anti-naturalism. These works traced the limits of natural scientific methods in the face of the felt reflexivity of the subject, the singular nexus of the individual's life, and the epistemic inability to comprehend life as a universally valid whole. Dilthey naturalistically critiques claims appealing to an uninterpreted immediate givenness and the direct self-access and self-evidence of uninterpreted "inner experience," while minimalistically confronting naturalism with the reflexively felt, interpretively processed, and reflectively conceptualized and mediated character of the given. Lived-experiences are complex relational wholes, involving purposiveness, which cannot be reduced to discrete "natural" elements abstracted from the life-nexus. Naturalism is the primary orientation of modern science; yet the contents of life and the objects themselves call us to methodological differentiation and the articulation of reality in more complex and multifaceted ways.
\end{abstract}

\section{Introduction}

Wilhelm Dilthey's epistemic project is to a certain extent "naturalizing," as his Neo-Kantian, phenomenological, and later hermeneutical critics have noted. At the same time, it is "anti-naturalistic" according to the positivistic and scientistic reception of his works. It is ironic that a holistic thinker of the self-generative interconnected "life-nexus" [Lebenszusamenhang] has been identified in this reception with a dualistically (mis-)construed reification of the distinction between nature [Natur] and spirit [Geist], and explanation [Erklärung] and understanding [Verstehen].

In this essay, I suggest a more complex and nuanced approach to Dilthey's thinking of nature and spirit that reveals his current relevance to ongoing debates between proponents of naturalism and anti-naturalism by reconsidering the mediated nexus of nature and history articulated in Dilthey's works, particularly the writings of the 1890s that are closer to a naturalistic and positivistic perspective without embracing it. I argue that Dilthey's project is more coherent than his naturalistic and anti-naturalistic critics have proposed. Such a reconsideration of Dilthey's project offers a significant alternative strategy for responding 
to the opposition between naturalism and anti-naturalism that continues to inform contemporary philosophy.

Beginning with the naturalistic perspective presupposed by and established in the modern natural sciences, the "fact of science" that is the point of departure for Neo-Kantianism and positivism, Dilthey immanently unfolds its scope, possibilities, and limits in relation to the psychological, historical, and ethical life-contexts of concrete embodied individuals. He does so without relying on essentialist religious or metaphysical conceptions of being, ideal validity, or an unchanging self. Dilthey not only accepted the validity of the modern natural sciences, he sought to clarify and justify them by historically and anthropologically contextualizing them. Nature and history do not necessarily indicate the elimination of knowledge and truth in relativism and skepticism, as Husserl feared in his polemical "Philosophy as Rigorous Science"; they are its contexts and conditions as Husserl later emphasized in a line of thinking that culminated in The Crisis of European Sciences and Transcendental Phenomenology. ${ }^{1}$ Without these life-processes, and the emergence of the cognitive from the non-cognitive, and rationality from the life-nexus, there would be no science as a socially constituted practice of knowing or as the human enactment of truth.

\section{The Promise and Crisis of Naturalism}

Dilthey's attention to natural science and writings about the historical formation of the modern natural sciences and the naturalistic life-comportment are underemphasized. ${ }^{2}$ In these writings, such as his account interpreting the constitutive role of Stoicism in the formation of early modern natural philosophy, Dilthey helped pioneer the history of science as a philosophical enterprise. ${ }^{3}$ Dilthey's this-worldly and historical justification of the sciences, and corresponding transformation of the modern project of epistemology, critically traced the extent and limits of scientific knowledge in the life-nexus and context.

1 Husserl 1981; Husserl 1970.

2 In addition to works on the emergence of modern science, Dilthey discussed contemporary natural scientific developments in review essays published in DGS volumes 15-17. References to Wilhelm Dilthey's works are to: Gesammelte Schriften, 28 vols. Göttingen: Vandenhoeck \& Ruprecht, 1914-2011 (cited as DGS); English translations are from Wilhelm Dilthey, Selected Works, ed. R.A. Makkreel and F. Rodi. Princeton: Princeton University Press, 1985- (cited as SW).

3 See the essays in DGS 2; on Dilthey's account of the transition to modern science and modernity, see Frohman 1995. 
Dilthey's rethinking of the epistemology of the sciences required their socialhistorical contextualization; the sciences are rethought in relation to their psychological, anthropological, and natural conditions that are embedded and enacted in historically mediated forms of life yet irreducible to pure historicity. In the context of the natural-historical finitude of human life, Dilthey contested reified visions of human reason with the felt self-relational reflexivity [Innewerden] of the self, the singular individuation of natural and historical life in an individual life, and the inability of humans to fathom and comprehend the whole of life as an integrated universally valid metaphysical system.

Dilthey's critique of historical reason revealed the conditional on-going process character of knowledge and the one-sidedness of the claims of the naturalistic worldview. The idea of truth in the naturalistic worldview that orients natural scientific inquiry has no theoretical limits in the continuing practice of the natural sciences. The natural standpoint enters into crisis and aporia when it is illegitimately extended beyond its experiential life-contexts and reified as a metaphysical world-system independent of its life-nexus. ${ }^{4}$

Dilthey's double strategy naturalistically contextualized epistemic claims involving an appeal to what transcends experience and the categories of life enacted through experience, while hermeneutically resituating claims about nature and naturalness. He rejected the naïve empiricism and intuitionism that entail appeals to a non-interpreted immediate givenness. For Dilthey, there is no access to experience independent of the mediation of expression and understanding; the direct self-access and transparent self-evidence of an uninterpreted intuitionist "inner experience" or an unmediated empiricist "sensuous experience" prove to be illusory. In contrast to vulgar life-philosophy and growing irrationalist appeals to a pure stream of life without the mediation of words and concepts, which Dilthey would challenge with a scientific conception of life-philosophy for the sake of life that cannot live without knowledge, Dilthey noted how concepts and intuitions are inappropriately separated from their life-contexts. Through the overextension and abuse of both reason and intuition, lived-experiences are fixated and dynamic life-perspectives become reified metaphysical world-pictures.

Dilthey's critical defense of naturalism is a limited and conditional one insofar as he resituated naturalistic claims vis-à-vis the subject in the experience. Dilthey's epistemic subject is a situated, experiential, and embodied one within the life-nexus. Insofar as it involves more than being an impersonal product of natural and social forces, this experiential subject requires a "weak transcenden-

4 On Dilthey’s hermeneutical empiricism, see Nelson 2007. 
tal" argument. Dilthey liberalizes the naturalistic thesis through this completely conditional yet still significant and meaning-creating self. Due to Dilthey's moderate nominalism and experientialism, Dilthey minimalistically reinterpreted Kantian a priori transcendental categories as conditionally enacted and contextually embodied life-categories [Lebenskategorien]. Dilthey confronted naturalism, as the exteriority of worldly causal relations, with the reflexively felt and interpretively mediated character of the phenomenally given and the factical in the lived-experiences of an individual life that is experienced as my own.

The experiential hermeneutical perspective of an individual life cannot disregard or escape the natural causal relations with which it is entangled. This contingent self, as the individuation of meaning in the midst of its natural and social conditions, cannot be coherently and adequately reduced to, or reconstructed as, a discrete set of "natural" elements abstracted from the complex life-nexus. In the co-givenness of self and world, spirit and nature, to be a self is to have a world "there-for-me." The world, as a relational nexus of significance, presupposes its being-there for someone. The individual is ineffable from the perspective of the natural standpoint. It is the individual person as a living ethical reality that is the other defining feature of modernity and the primary focus of the human sciences in Dilthey's historical analysis.

Despite the role of the ethical individual in the human sciences, naturalism is the primary methodological orientation for all modern science. Yet it is exposed to a dialectic that results in dogmatic metaphysical theses and explosive aporias that force its liberalization. The naturalistic standpoint is caught in perplexity and crisis in being extended to ethical life and challenged with issues of value, purpose, and meaning that it cannot appropriately address. It is the contexts and contents of life-as mediating nature and spirit-that motivate the methodological differentiation of the sciences and the articulation of reality in more complex and multifaceted ways.

\section{Dilthey and Naturalistic Positivism}

Dilthey's name is invoked in Anglo-American contexts in conjunction with the idea-articulated by C.P. Snow-that the natural sciences and humanities constitute two distinct cultures. Dilthey is understood as a radical dualist in this discussion and this remains the predominant way of construing his distinction between interpretive understanding in the human sciences and causal explanation in the natural sciences. Moreover, Dilthey has been interpreted as proposing the supremacy of one culture over the other within philosophical discourses. 
One reading of Dilthey identifies his project's basic tendency as in some sense "naturalizing" and "positivistic." Although this judgment might appear peculiar, Dilthey himself affirmed the family affinity between these two movements-along with materialism-as developmental variations of a common "natural standpoint" or "natural worldview." Dilthey not only noted their affinity with and resonance with one another but with his own critical empirical project that also begins with the fact of the modern natural sciences. Broadly construed, the naturalistic standpoint encompasses a guiding commitment to a non-supernatural and scientific conception of the world. Naturalism is transformed into natural scientific positivism, according to Dilthey, when the critical standpoint of the phenomenal character of the physical world is recognized. ${ }^{5}$ The positivist turn in the modern natural sciences entails that naturalism and materialism as doctrinal metaphysical systems or theses about reality are abandoned.

Dilthey's later hermeneutical critics maintain the continuity between Dilthey and scientism. ${ }^{6}$ Heidegger claimed that Dilthey's differentiation of two varieties of sciences, natural and human, remains a positivistic distinction. It is derivative of the more original question of being [Sein] as such and as a unified whole in contrast with the ontic investigation of beings as entities [Seiende]. Gadamer maintained that Dilthey was trapped between the scientistic methodologically reductive conception of the world and the romantic experience of an affectively moved and felt vital individuality. ${ }^{7}$ Because of his affinity with positivism, Gadamer has stressed how Dilthey remained a student of Comte and Mill as well as of Goethe and Schleiermacher. This characterization of Dilthey makes little sense if "naturalistic positivism" is defined in the limited sense of, in Croce's words, "the enemy of everything spiritual and historical." 8 An expanded and historically fairer exposition of positivism, one that allows us to productively and critically clarify Heidegger and Gadamer's portrayal of Dilthey, is that it is naturalistic and positivistic in the sense that it encompasses: (1) the critique of metaphysical conceptions of reality for the sake of encountering and investigating reality in its empirical givenness and phenomenality and (2) the epistemic priority of the methods, models, and results of the modern natural sciences. Dilthey endorsed the former thesis while modifying the latter one with a broader conception of science that encompassed the natural and social-historical world.

\footnotetext{
5 DGS 5, p. 403.
}

6 On Dilthey and positivism, see Sommerfeld 1926; on Heidegger's analysis of Dilthey's positivism as the culmination of metaphysics, see Gander 1988.

7 Gadamer 2004, p. 214.

8 Croce 1941, p. 129. 
In another variation of this criticism, developed in Georg Simmel and adopted by Walter Benjamin and Theodor Adorno, Dilthey could not overcome the last residues of naturalistic biology and universalistic anthropology by adequately historicizing and socializing human existence. ${ }^{9}$ This restraint is intentional. Dilthey opposed the historical school's one-sidedness as much as reductive naturalism. Dilthey's anthropological dimensions were critiqued by historicizing thinkers on the right and the left. In an early response to Dilthey's criticism of the notion of a folk soul [Volkseele], or collective agent, Simmel contended that there are no real individuals for the same reasons that Dilthey used to conclude that there are no real collective entities. The collective and the individual are equally constituted products of natural conditions and social forces. ${ }^{10} \mathrm{Sim}$ mel proposed that this position, Dilthey's hermeneutical o individualism is left unnamed, was a positivism that inconsequentially stopped short in the face of the myth of the person. ${ }^{11}$

\section{Dilthey and Anti-Naturalism}

A second way of reading Dilthey has made his thought the target for proponents of the thorough naturalization of the human sciences and everyday life. Dilthey appears as a major antagonist of scientific naturalism from Otto Neurath's polemical assessment to Mantzavinos's Naturalistic Hermeneutics. According to this argument, Dilthey cannot successfully prove that the human and natural sciences are discrete autonomous unities and that this thesis dangerously undermines the unity, coherence, and integrity of the sciences. ${ }^{12}$ Dilthey is read as placing inherent limits on the progress of positive scientific knowledge and rejecting a naturalistic conception of the world for one inhabited by biographical persons, felt and conceptual motivations, social groups, cultural patterns, political institutions, and other mythical folk-concepts. Dilthey's differentiation of the human sciences consequently places them outside the realm of legitimate scientific inquiry. The expanded notion of rationality and science promoted by Dilthey inevitably leads to irrationality and anti-science for these critics. This positivist criticism is echoed in Marxist materialism; Lenin and Lukács depicted Dilthey

9 On Benjamin's reading of Dilthey's as an anthropologically based and naturalistic opponent of radical historicity, see Hanssen 2000, p. 53.

10 Compare Udehn 2001, pp. 68-74.

11 Udehn 2001, pp. 68-74.

12 Neurath 2006, p. 285; Mantzavinos 2005. 
and Weber's justification of interpretive understanding [verstehen] in the human sciences as a higher obscurantism and non-clerical form of idealism. ${ }^{13}$

There are earlier suspicions concerning the meaning and implications of interpretive understanding, which is the elementary stumbling block for Dilthey's science oriented commentators. Theobald Ziegler warned in the late $19^{\text {th }}$ century of a "dictatorial Ignorabimus" ("we will not know") that he proposed stemmed from Dilthey's interpretation of Augustine. Dilthey emphasized Augustine's articulation of an irrational subjective interiority and ineffable individuality that can only be comprehended through an intuitive felt understanding. Such a feeling-tofeeling transmission between persons cannot be reproduced and thus endangers the objectivity and rationality of science.

A disagreement concerning Dilthey's import for the sciences is evident in the von Mises brothers. The Austrian school economist Ludwig von Mises accepted Dilthey's methodological individualism, criticized by Simmel, and the incalculable character of life in the 1920s in his confrontation with Neurath's conception of socialist calculation. The logical positivist Richard von Mises maintained, however, that ignoramus et ignorabimus-the "we do not know and will not know" that Emil Du Bois-Reymond introduced in a 1872-is a consequence of Dilthey's differentiation of explanation [erklären] and understanding [verstehen]. ${ }^{14}$

Walter Pollack and Georg Misch argued against the claim that understanding the finitude and conditionality of cognitively established theoretical knowledge as entailing an obscurantist prohibition on further research and inquiry. ${ }^{15}$ Dilthey rejected in his discussions of Du Bois-Reymond's thesis the idea that there are intrinsic limits to scientific inquiry even as he argued that the sciences are internally differentiated and varied by their objects of inquiry. ${ }^{16}$ The scope and unity of science are not to be dogmatically limited from outside; the sciences are differentiated through the multiplicity that constitutes the empirical world. Dilthey would consequently agree with Haeckel's critical reply-Impavidi progrediamur ("advance fearlessly")-to Du Bois-Reymond's ignorabimus and Virchow's restringamur, while disputing positivistic claims about the import of the sciences within everyday life.

In a Literaturbrief from 1876, Dilthey describes how Du Bois-Reymond's thesis is as unscientific as the dogmatic scientific materialism that it opposes. ${ }^{17}$ The

13 On Dilthey's relationship with Marxism, see Rockmore 1992, p. 212.

14 Mises 1968, p. 209.

15 Pollack 1907, p. 119; Misch 1947, p. 49.

16 Pollack 1907, p. 119.

17 DGS 17. 
current configuration of the scope and limits of the sciences can and will be redrawn. Crises and alternative hypotheses and theories reconfigure the scope and limits of scientific knowledge. However, inclining toward Hume's argumentation concerning what theory and scientific theory can achieve, and prefiguring Carnap's distinction between science and ethics, Dilthey concluded that there are no internal limits to science in its own domain yet, even if every question could be scientifically resolved into natural laws, the riddles and tasks of practical life would still remain unanswered. ${ }^{18}$

Jürgen Moltmann argued that Dilthey did not advocate obscurantism in response to science and reason. Dilthey identified a scientistic obscurantism in the disregard of historical life, and delusion that truth is gained independently of its intersubjective conditions. ${ }^{19}$ Their ahistorical lack of vision resembles the priestly princes of metaphysics who refuse to acknowledge the constitutive role of the affective, the subjective, and the individual that are the conditions of both life and knowledge. No desires and sentiments run through the veins of their knowing subjects and such subjects are constitutively incapable of living and knowing. The thesis that reason is grounded in sentiment and historical life is another argument with precedents in Hume's philosophy of common life.

Misch maintained that Dilthey adopted the same phenomenalist epistemic basis as the positivist advocates of the natural sciences, whilst reinterpreting its significance. There can be in Dilthey no "we will not know" that limits processes of intellectual development. ${ }^{20}$ There is only a reasonable recognition that we cannot know in an absolute "royal" way. This pluralist claim cuts against both reductionistic naturalism and anti-naturalism. Insofar as anti-naturalism assumes a royal route to truth through intuition, dialectic, or abstract reason, it commits the same error as its opponents. ${ }^{21}$

There is a suggestive alternative conception of nature and spirit in Dilthey. Ermarth describes him as an idealist inculcated "with a considerable dose of naturalism.” But more adequately, as Dilthey did not idealistically deny natural and social exteriority, others stress Dilthey's intermediate and mediating role in these disputes. ${ }^{22}$ Dilthey articulated an expansive and liberal in contrast with a cramped and illiberal naturalism; one encompassing value, validity, and the ideal as

18 On Carnap's relationship to Dilthey and Heidegger, see Nelson 2012 and Nelson 2013a.

19 Moltmann 1971, p. 60.

20 Misch 1947, p. 49.

21 Harrington contends that Dilthey cannot be assimilated to either naturalism or the anti-naturalism of Husserl and Neo-Kantianism in Harrington 2001. Compare the arguments for a common anti-naturalism in Jalbert 1988.

22 Keller 1895: 126. 
the content of consciousness in accordance with a scientific- and person-oriented principle of phenomenality [Satz der Phänomenalität] in which nature and the world are not neutral and impersonal but "there-for-me." ${ }^{33}$

\section{Nature and Spirit}

In a late short retrospective piece, his "Draft for a Preface" (1911) for a collection of his epistemological and psychological writings, Dilthey noted that the dominant positivist model of the natural sciences had "truncated the spiritual-cultural world" by transforming it into a mere folk-illusion. ${ }^{24}$ This illusion-from the perspective of mere natural material relations-is, however, not a groundless illusory projection but functionally real in how individuals live. The most reductive naturalist and materialist presuppose the practices of the human world and the enactment, expression, and understanding of human life. All sciences presuppose this life-nexus. But it is this practical life-context, which has been bracketed by the natural sciences, that allows human scientists to recognize the individual self in its sociality and its productive creative relations with the whole of its life.

Dilthey revealed the aporias of constitutive idealism and its problematic intellectualist and representationalist assumptions about mind and reality, arguing that life is given through its phenomenality. Yet life is not merely a phenomenal appearance constituted by an empirical much less an ideal consciousness. It is significant for someone. Whereas only nature comes from nature, life in its relational tensions and living actuality is "there-for-me." Life is given as a complexly mediated productive nexus that can form awareness, meaning, and value for itself. This relationally emergent life is in need of words and the cultivation of its relational capacities for expression. As such, life is not immediately or intuitively given to itself. It is reflexively aware, which is "the most simple form in which psychic life can appear." ${ }^{25}$ The simple and elemental is already reflexively relational and mediated. That is to say, it must be understood and interpreted through its expressions, objectifications, and practices. There is no knowledge of a world independent of perception and lived-experience, which provide the context and actuality for idealism's consciousness and naturalism's material nature.

23 DGS 5, p. 90; SW I, pp. 245-246.

24 SW II, p. 2.

25 DGS 19, p. 66; SW I, p. 254. 
The naturalizing approach to reality based on a materialistic understanding of the natural sciences continues to be the prevailing tendency of our time despite the anti-naturalistic calls to re-enchant the world and the theological turn in some forms of recent philosophy. The anti-naturalistic distrust of the sciences is scrutinized by Dilthey in the same preface. Dilthey maintained that it is not modern science and its successes that are the problem but the triumph of a narrow conception of scientific method over science.

Despite the limitations and dogmatic overextension of positivism, and thus of the naturalistic worldview as a metaphysical doctrine about the totality of the world, Dilthey articulated the empirical dynamic of knowledge while rejecting positivism's speculative opponents, "who tore thought away from sense-perception." 26 According to Dilthey, both positivism and Kantian inspired critical empiricism are correct to stress both experience and its limits, since the natural and historical empirical conditions and contexts of life cannot be transcended even as further articulation and evaluation pushes individuals beyond the factuality of real conditions.

In contrast to the one-sided reduction of life to biological and physiological instincts, drives, and the senses that are its natural basis or to the activity of a non-sensuous spirit or constitutive consciousness, Dilthey proposed a suggestive alternative strategy: to "understand life on its own terms," immanently interpreting it from out of itself-without eliminating its fullness for the sake of one of its elements-and bring it through its felt reflexivity, methodological interpretation and inquiry, and self-reflection [Selbstbesinnung] to reflective cognition and validity about itself. ${ }^{27}$ To this extent, science [Wissenschaft] is not excluded or demeaned, as Dilthey's scientistic critics maintain. It has a central role-along with art and ethics-in the formation [Bildung] and self-reflectiveness [Besinnung] of modern individuals in relation to the contingency of natural forces and social conditions.

Dilthey remarked earlier in Life and Cognition (1892-1893) that "thought, which sets out to ultimately comprehend the universe, is bound to the transient existence of organic life. Thought is fragile; it appears only at isolated points in organic life and as such only at intervals as a temporary function. Everywhere it appears as a part of life and in its service." ${ }^{28}$ Dilthey is pursuing here a naturalistic strategy insofar as he analyzes how things emerge from contingent natural conditions and circumstances and the common bodily sensuous schema of ani-

26 SW II, p. 2.

27 SW II, p. 2.

28 SW II, p. 345. 
mal and human life. Thought strives to universalize itself, and the person to individuate herself in the context of these life-conditions. This universalizing from out of the facticity and finitude of one's situation and milieu is possible because of the pre-conceptual felt self-reflexivity and the intensified self-reflectiveness in which life turns back on itself and through which life becomes aware of itself, articulating itself as $a$ life. $^{29}$

The individuation and cultivation of a self occurs through an immanent intercrossing movement, encompassing the natural-biological as well as the social-historical, toward the possibility of the ideal and potentially even the religious. It is here that the ethical, the individual other worthy of respect, becomes visible within the context of the world and society. Dilthey described this process of the becoming of knowledge as "a real natural epistemology." It requires an expansive conception of naturalness, without doctrinal naturalism's confinement of the phenomena, in contrast with its reductive and eliminative forms.

\section{Becoming a Self}

Dilthey did not conclude his argumentation with the assertion of naturalness in this expanded sense. Dilthey critically traced the boundaries of natural scientific methods in the face of the felt reflexivity of the subject, the singular nexus of the individual's life [Individuation], and the inability of humans to know and comprehend life as a comprehensive universally valid systematic whole. Beginning with naturalism as a general point of departure in his writings of the 1890s, Dilthey immanently demonstrated its possibilities and limits in the context of the psychological, historical, and ethical life of individuals while declining to appeal to essentialist, religious, or metaphysical conceptions of a substantialized self.

Dilthey's project extends beyond the theory of knowledge as it is shaped by the concern for recognizing and valuing an ethical individual self within the context of the natural and social-historical determinants that appear to undermine the identity of such a self. Dilthey does not consequently posit a self as an atom of analysis outside the social, as Simmel charged, since Dilthey articulated the individuation of a thoroughly relational self. Simmel dismantled this individuality, which for Dilthey is not merely a theoretical thesis but a practical vocation, as an undigested naturalistic remnant resisting full social mediation. There is nei-

29 See Nelson 2011a. 
ther an unmediated individual nor an ahistorical biological organism in Dilthey. He revealed how the self is expressed and cultivated only within and through the immanent structures and conditions of social-historical life. The individual self establishes itself and other selves as a universal value in and through this nexus, as an intersectional point of intercrossing forces that extend beyond it in processes of individuation.

Dilthey's practical ethical orientation constituted the genuine turning point from the natural to the human world. This transition from nature to spirit furthermore has its own epistemic conditions. While Dilthey naturalistically critiques claims appealing to a non-interpreted immediate givenness and the direct selfaccess and self-evidence of an unmediated "inner experience" or an unmediated sensuous perception, which lead to problematic transcendent claims about reality as a systematic totality, Dilthey critically-if minimalistically due to his reinterpretation of transcendental categories as embodied life-categories-confronts naturalism with the reflexively and interpretively processed and mediated character of the given and the factical. Since facticity and givenness must be therefor-me (there for a self) as lived-experiences are complex relational wholes involving purposiveness, Dilthey concludes that they cannot be coherently and adequately reduced to discrete "natural" elements abstracted from the complex life-nexus.

Naturalism is the most fundamental worldview and the primary orientation of modern science in Dilthey's Weltanschauungslehre; but the contents of life and objects themselves necessitate methodological pluralism and articulating reality in more multifaceted and nuanced ways.

\section{Psychology's Mediating Role}

Dilthey reinterprets epistemology as having a social, psychological, and biological dimension that cannot be eliminated without distorting the activities, processes, and tasks of cognitive knowledge [Erkenntnis] in the context of articulating and justifying ordinary and human scientific communicative understanding. Dilthey challenges metaphysical and scientistic formalisms that interpret knowledge to consist of worldless validity and value claims. The sense of actuality is not a product of intellectual positing; it is shaped by the interaction of cognition with feeling, instincts, and volitions that develop as a complex whole in a person through experiences of resistance, limitation, and restraint.

"The Origin of Our Belief in the Reality of the External World and Its Justification" (1890) illustrates how reality is neither a representationally constructed phenomenal object nor an immediately given in intuition or inner experience. 
Reality as "there for me" is exhibited as immediate in empirical consciousness through felt reflexive awareness [Innewerden]. This apparent immediacy is mediated through biological drives, environmental adaptations, and practical interests formed through the play and work of impulse and resistance. Our sense of reality presupposes the elemental interaction and mediation of self and world prior to their differentiation; reality is irreducible to a worldless subject or an unperceived and non-given object, to pure consciousness or materiality, or their metaphysically reified manifestation as idealism and materialism.

Dilthey's philosophical and psychological writings from the 1890s represent a highly productive and controversial period in his intellectual development. Dilthey's endeavors to give both naturalistic and humanistic strategies their due regard and reconceive epistemology through the methods and data of the sciences, particularly history and psychology, led to the negative reaction of both positivists and idealists. No aspect of his thought was more provocative than his advocacy of a descriptive and analytic psychology as a "human science" [Geisteswissenschaft], which was opposed by those who considered psychology an exclusively naturalistic experimental science, including pioneering experimental psychologists such as Ebbinghaus and Wundt who pursued reductionist programs that uprooted individuals from their environing world and social existence. Dilthey's critics included Neo-Kantian philosophers. Windelband and Rickert protected the distinctiveness of the "cultural sciences," as sciences of individual persons and ideal values, from naturalism by abandoning psychology to the universalizing hypothetical-causal natural scientific explanations.

These debates continue to haunt later reflections on the possibility of a humanistic or interpretive psychology. Dilthey's contributions to these disputes over the actuality of the self and its experiences of the world are worth reconsidering for their historical significance, and-given the increasing albeit still too limited appreciation for the social, historical, cultural, and aesthetic dimensions of psychological inquiry-because we are perhaps in a better position today to recognize the continuing relevance of Dilthey's contextualizing epistemology and individual-oriented interpretive psychology. ${ }^{30}$

“The Ideas for a Descriptive and Analytic Psychology” (1894), Dilthey's most controversial work, raised the ire of positivistic psychology (Ebbinghaus and Wundt) and philosophers committed to a transcendental realm of validity and value claims (Rickert and early Husserl). Dilthey articulates-through a complex and nuanced reading of the psychological literature of his times-the possibility of a descriptive and analytic (interpretive) psychology. He did not maintain an

30 On the impure plural character of Dilthey’s psychology, see Nelson 2010. 
opposition of methods-understanding and explanation-and a duality of sciences-natural and human. Dilthey does not advocate abandoning or bracketing the causal nexus of reality; he reminds his readers that mechanical and efficient causal explanation in the natural sciences construct an abstract causal nexus linked by hypotheses and separated from the dense bonds and thick relations of life's effective nexus [Wirkungszusammenhang].

In kinship with Max Weber's later conception of interpretive understanding, relations of meaning and causal relations are mutually entangled. Neither one dissolves the efficient causal and conditional nature of scientifically explainable reality. Nowhere is the connectedness of meaning and causality more significant than in the human sciences themselves. Dilthey consequently did not reduce human scientific inquiry to pure interpretive understanding. Dilthey utilized both efficient causal explanation and interpretive understanding in his psychology as well as other human scientific strategies such as functional and structural explanation of social and cultural systems.

Dilthey did not deny causality; he critiqued the misuses and abuses of causality in reductive empirical experimental psychology and scientism for the sake of genuine scientific inquiry. Misch identified Hume as an important source for Dilthey's historical project. As with Hume's moderate and life-nexus oriented skepticism, which can be employed against dogmatic metaphysics and radical skepticism, Dilthey interrogated the possibility of fathoming causal connections to achieve certainty or metaphysical truth, whether this is materialist or idealist, while articulating the social reproduction and transformation of meaning and knowledge within the contexts of the daily communicative practices of everyday life. Counter to justifying the sciences through an appeal to a transcendent reality or transcendental conditions, Dilthey followed a Humean strategy of defending the sciences by skeptically abandoning exaggerated knowledge claims and through the sciences' anthropological-historical contextualization. ${ }^{31}$

Given the mediation involved in concrete individual life, psychology cannot be appropriately understood as a subjective self-intuition and introspection. This approach denies the facticity of life and mind, as mediated phenomena demanding interpretation, and undermines psychology's scientific-intersubjective and universalizing - task. Nor is psychology adequate to its task of illuminating individual human life if it is the collecting of discrete data-abstracted from and dissolving the life-nexus of individual and social life-externally reconstructed and organized through causal hypotheses.

31 This reading runs contrary to the account in Beiser 2012, p. 433. 
Objectifying third-person methods are useful in science but should be contextualized in a human-oriented psychology that recognizes the conditional, negotiated, and fragile unity and identity of the individual person and the person's interpretive, mediated, and self-reflexive life. Because of the multifaceted mediation of the "acquired psychic nexus," which as structured contrasts with an atomistic bundle of elements and as acquired differs from the vision of an innate intrinsic self, psychology cannot be merely descriptive but must also be analytic, comparative, and structural. Structural psychology reveals the temporal enactment of the categories of life in lived-experience and provides additional support for his reinterpretation of epistemology and the human sciences in contrast with movements that disregard empirical psychology.

Dilthey did not abandon this psychological program even as it became more deeply hermeneutical in his later works. "Contributions to the Study of Individuality” (1895-96) further articulates the comparative-morphological strategy of elucidating individuality in its relational contexts. Through the hermeneutical oscillation between singular and whole, both are further elucidated. Dilthey rejected Windelband's Neo-Kantian model of the ideographic character of the cultural sciences developed. Dilthey illustrated how (1) natural sciences such as astronomy encompass an ideographic dimension and (2) the human sciences presuppose and propose generalizing and systematizing claims that allow the effective life-nexus to be interpreted through the typical and the singular. It is in such natural-historical contexts that the actual and not merely ideal individual can be recognized and respected.

The world overflows the individual for Dilthey: "The infinite richness of life unfolds itself in individual existence because of its relations to its milieu, other humans and things. But every particular individual is also a crossing point of contexts which move through and beyond its particular life ..." ${ }^{32}$ The conditional and situated yet meaningful and purposive individual person is the basic point of departure and task for the human sciences and of Dilthey's hermeneutical justification of methodological individualism against the radical collectivist tendencies dominant in German cultural criticism and social theory.

Dilthey's methodological individualism differs from other varieties because it grasps the individual as a contextual historical reality rather than as a Hobbesian fiction and allows for the use of social concepts. Social realities such as the state, society, and community are given in experience and need to be interpreted in order to understand social life. Their experiential givenness does not justify positing them as independent much less metaphysical realities. Dilthey's cri-

32 DGS 7, p. 135. 
tique of reified notions of the spirit of the people [Volksgeist] and community [Gemeinschaft] for the sake of the relational yet distinctive individual, which was reformulated by Plessner in response to its fascistic forms, proved to be prescient. ${ }^{33}$

\section{Naturally Interpreting Persons}

Dilthey's philosophy of the human sciences appears anti-naturalistic from the perspective of an impoverishing and reified monistic naturalism. Dilthey's quasi-naturalism is such that the appropriate recognition of each object and class of objects calls for recognition. It is methodologically pluralistic and opposed to the minimalistic naturalism of philosophers like Quine. From Quine's eliminative viewpoint, Dilthey would appear even more dogmatically empirical in his defense of the unrestricted and unprejudiced empirical inquiry [unbefangene Empirie] against empiricism and more laxly lenient and baroque than Carnap's-from Quine's perspective-overly tolerant logical positivism.

Dilthey's critique of metaphysics places transcendent objects into suspicion as being beyond the limits of cognitive knowledge. This critique does not extend to phenomenal objects given in experience, all of which (natural and human) are mediated. The mediation of each object does not entail a reduction to isolated elements that suppresses their sense and significance. It requires that they be described and analyzed as wholes. Although sciences are expressions of life, which cannot escape life's conditions, the human sciences are constituted in intersubjective relations by ethical and social-political interests in a way that distinguishes them from the natural sciences that rest more securely in the objectified world.

Dilthey's vision encompasses naturalism without being limited by it. His strategies prefigure philosophical anthropology in Misch, Plessner, and Scheler. This contextualized, nuanced, and tolerant form of historically contextualized and liberated-as a human attitude and product-naturalism proceeds from the natural-biological and anthropological conditions of human life through their social-historical configurations to their unique intersection in the life, self-reflection, and individuation of a conditional yet meaningful and purposive nexus of an individual biographical life.

Heidegger construed Dilthey's project as a flawed anti-naturalist personalism and consequently a failed phenomenology that gave the naturalistic and sci-

33 Plessner 1999. 
entific perspective too much purchase. ${ }^{34}$ Dilthey's works are an ambiguous source for the new phenomenology, as Husserl noted in his defensive justification in "Philosophy as Rigorous Science" of the primacy of an absolute science opposing all natural, anthropological-psychological, and social-historical conditions and contexts. ${ }^{35}$ Given their common sources in the descriptive and analytic empiricist philosophy of Trendelenburg, Dilthey appreciated the description of the emergence of higher forms of understanding, meaning, and validity described in Husserl's Logical Investigations and its tendency toward the a realist worldly referentiality. Husserl, Scheler, Heidegger learned from Dilthey's psychology and depiction of an immanent self-interpreting affective, worldly, and historical life. ${ }^{36}$

Dilthey's project is incommensurable with the Neo-Kantian and phenomenological transcendental-ontological turn in philosophy. Dilthey did he bracket the natural and the objective for the sake of a pure phenomenological starting point that is independent of the social-historical life-nexus. He would not attempt to replace metaphysics-placed in doubt by cultural-historical and epistemic-reflective critique and revealed to be more affective and individual than cognitive and universal-with a new transcendental-ontological philosophy. Philosophy should become a more modest project of critical reflectiveness that cannot abandon its close relations with either the natural and human sciences or with the questions of practical life. The multiplicity of ways of life and worldviews is in this context irrevocable. ${ }^{37}$ Human life's intercontextuality and the value of individual personality are articulated through interdisciplinary human scientific research. As von Aster noted, metaphysics is abandoned in Dilthey for philosophical anthropology and universal history. ${ }^{38}$

Aster and Misch maintained that a philosophical reflection that informs and is informed by the human sciences and modestly remains within the immanence of nature and life is incompatible with the rehabilitation of the metaphysical, theological, and transcendence in the phenomenology of the 1920s. ${ }^{39}$ Misch describes how Dilthey's anti-metaphysical critical philosophy directs us back toward empirical life and its problems, while the new "life-philosophical" ontology departs from that life to return to the metaphysical. ${ }^{40}$ Dilthey's advocacy of the

34 Heidegger 1985, GA 20, p. 161. See Nelson 2013b.

35 Husserl 1981.

36 See Heidegger, GA 20, p. 161; Aster 1935, p. 149, 155.

37 On Heidegger's criticism of Dilthey's “ontic pluralism," see Nelson 2011b.

38 Aster 1935, pp. 51-52, 103.

39 Aster 1935, pp. 103-104.

40 Misch 1967, pp. 281-282. 
Enlightenment's anti-metaphysical legacy and critical-positivist prioritization of experience and the experiential sciences are sources of resistance to the powers of authoritarianism and re-enchantment. ${ }^{41}$

\section{Feeling and the Transformation of Nature in Dilthey's Aesthetics}

Dilthey's aesthetics provides another example of his resistance to enchantment and critical appreciation of naturalism and modernity. Dilthey's aesthetics has been portrayed as a continuation of Romanticism that-due to the emphasis on feeling, imagination, and the free responsiveness of the subject-is incompatible with $19^{\text {th }}$ century realism and naturalism. But in his aesthetic writings, particularly "The Three Epochs of Modern Aesthetics and Its Present Task" (1892), Dilthey emerged as a more sympathetic aesthetic theorist who criticized the limitations while articulating the significance and possibilities of literary realism and naturalism-e.g., modern artistic articulations of the naturalistic feeling of life-against their Neo-Romantic detractors and the emergence of symbolist spiritualism with its visionary enthusiasm.

Realism's power lies in how it critically reveals the discrepancy between outer appearance and internal reality, even as its weakness is its inability to reflectively generalize and interpretively focus on what is essential to evoking and heightening the "feeling of life." Rather than defending Romantic aesthetics and rejecting naturalism and, naturalism is understood as achieving its truth when it not only copies and reproduces but elucidates, intensifies, and transforms the life it portrays. Dilthey reinterprets realism through the tension of reality and feeling, resistance and will, and the objectivities of social life and lived-experience of the individual.

The naturalism of social novels expresses the emergence of a new style and sensibility appropriate for the modern technological conditions of life that has not yet achieved a "new inner form" for the work of art in relation to the subjectivity of the artist and audience. Dilthey reinterpreted both romanticism and realism as revealing two sides of the tensions of reality and feeling, resistance and will, and the objectivities of social life in the relational context of individual lived-experience.

Life-philosophically and hermeneutically interpreted, the aesthetic realism and naturalism prove to be one-sided and incomplete in contrast to the expan-

41 Misch 1967, pp. 281-282. 
sive and liberal unfolding of naturalism in Goethe. Dilthey emphasized the naturalistic dimensions of Goethe and Schleiermacher, relying on them to formulate his objections to narrow naturalism. Nonetheless, despite his criticisms, literary naturalism and realism are more aesthetically promising for the "present task of aesthetics" than the abandonment of the tension between reality and feeling in a romantic literature that one-sidedly embraces organic vitality, intuitive vision, and irrational feeling. Dilthey's critique of radical subjectivism in aesthetics illustrates his wider hermeneutical empiricist strategy of critiquing idealism by resituating spirit within social-historical, psychological, and natural life-conditions. Dilthey is accordingly an ambiguous heir to Romanticism and a critic of its pathologies.

\section{Acknowledgments}

An earlier version of this chapter appeared as Eric S. Nelson, "Between Nature and Spirit: Naturalism and Anti-Naturalism in Dilthey," in: Giuseppe D'Anna, Helmut Johach and Eric S. Nelson (eds.), Anthropologie und Geschichte. Studien zu Wilhelm Dilthey aus Anlass seines 100.Todestages. Würzburg: Königshausen \& Neumann, 2013.

\section{References}

Aster, E. von (1935) Die Philosophie der Gegenwart. Leiden: A.W. Sijthoff.

Beiser, F.C. (2012) The German Historicist Tradition. Oxford/New York: Oxford University Press.

Croce, B. (1941) History as the Story of Liberty. London: Allen and Unwin.

Frohman, L. (1995) "Neo-Stoicism and the Transition to Modernity in Wilhelm Dilthey's

Philosophy of History." Journal of the History of Ideas 56(2): 263-287.

Gadamer, H.-G. (2004) Truth and Method. London: Continuum.

Gander, H.-H. (1988) Positivismus als Metaphysik: Voraussetzungen und Grundstrukturen von Diltheys Grundlegung der Geisteswissenschaften. Freiburg: Alber.

Hanssen, B. (2000) Walter Benjamin's Other History: Of Stones, Animals, Human Beings, and Angels. Berkeley: University of California Press.

Harrington, A. (2001) "Dilthey, Empathy and Verstehen: A Contemporary Reappraisal."

European Journal of Social Theory 4(3): 311-329.

Heidegger, M. (1985) History of the Concept of Time: Prolegomena. Bloomington: Indiana University Press.

Husserl, E. (1970) The Crisis of European Sciences and Transcendental Phenomenology: An Introduction to Phenomenology, tr. David Carr. Evanston: Northwestern University Press. 
Husserl, E. (1981) “Philosophy as Rigorous Science.” In: Husserl: Shorter Works, ed. Peter McCormick and Frederick A. Elliston. Notre Dame: University of Notre Dame Press, pp. $166-197$.

Jalbert, J.E. (1988) "Husserl's Position between Dilthey and the Windelband-Rickert School of Neo-Kantianism." Journal of the History of Philosophy 26(2): 279-296.

Keller, L., ed. (1895) Monatshefte der Comenius-Gesellschaft 4-5.

Mantzavinos, C. (2005) Naturalistic Hermeneutics. New York: Cambridge University Press. Misch, G. (1947) Vom Lebens und Gedankenkreis Wilhelm Diltheys. Frankfurt a. Main: G. Schulte-Bulmke.

Misch, G. (1967) Lebensphilosophie und Phänomenologie: Eine Auseinandersetzung der Diltheyschen Richtung mit Heidegger und Husserl. Stuttgart: Teubner.

Mises, R. von (1968) Positivism: A Study in Human Understanding. New York: Dover. Moltmann, J. (1971) Hope and Planning. New York: Harper \& Row.

Nelson, E.S. (2007) "Empiricism, Facticity, and the Immanence of Life in Dilthey." Pli: Warwick Journal of Philosophy 18: 108-128.

Nelson, E.S. (2010) "Impure Phenomenology: Dilthey, Epistemology, and Interpretive Psychology." Studia Phaenomenologica 10: 19-44.

Nelson, E.S. (2011a) "Self-Reflection, Interpretation, and Historical Life in Dilthey." In: H.-U. Lessing, R.A. Makkreel and R. Pozzo (eds.), Recent Contributions to Dilthey's Philosophy of the Human Sciences. Stuttgart: Frommann-Holzboog, pp. 105-134.

Nelson, E.S. (2011b) "The World Picture and Its Conflict in Dilthey and Heidegger." Humana.Mente: Journal of Philosophical Studies 18: 19-38.

Nelson, E.S. (2012) "Dilthey and Carnap: Empiricism, Life-Philosophy, and Overcoming Metaphysics." Pli: Warwick Journal of Philosophy 23: 20-49.

Nelson, E.S. (2013a) “Heidegger and Carnap: Disagreeing about Nothing?” In: F. Raffoul and E.S. Nelson (eds.), Bloomsbury Companion to Heidegger. London: Bloomsbury, pp. 151-156.

Nelson, E.S. (2013b) "Dilthey, Heidegger und die Hermeneutik des faktischen Lebens." In: Gunter Scholtz (ed.), Diltheys Werk und seine Wirkung. Göttingen: Vandenhoeck \& Ruprecht, pp. 97-109.

Neurath, O. (2006) "Soziologie im Physikalismus" (1931). In: M. Stöltzner (ed.), Wiener Kreis. Texte zur wissenschaftlichen Weltauffassung. Hamburg: Meiner, pp. 269-314.

Plessner, H. (1999) The Limits of Community: A Critique of Social Radicalism. New York: Prometheus.

Pollack, W. (1907) Über die philosophischen Grundlagen der Wissenschaftlichen Forschung, als Beitrag zu einer Methodenpolitik. Berlin: F. Dümmler.

Rockmore, T. (1992) Irrationalism: Lukács and the Marxist View of Reason. Philadelphia: Temple University Press.

Sommerfeld, H. (1926) Wilhelm Dilthey und der Positivismus: Ein Untersuchung zur "Einleitung in die Geisteswissenschaften." Berlin: J. Herper.

Udehn, L. (2001) Methodological Individualism: Background, History and Meaning. London: Routledge. 